\title{
Covering behavior of deep-water echinoids in Antarctica: possible response to predatory king crabs
}

\author{
Cecilia J. Brothers ${ }^{1, *}$, Kathryn E. Smith ${ }^{2}$, Margaret O. Amsler ${ }^{1}$, Richard B. Aronson ${ }^{2}$, \\ Hanumant Singh ${ }^{3}$, James B. McClintock ${ }^{1}$ \\ ${ }^{1}$ Department of Biology, University of Alabama at Birmingham, Campbell Hall 464, 1720 2nd Avenue South, Birmingham, \\ AL 35294, USA \\ ${ }^{2}$ Department of Biological Sciences, Florida Institute of Technology, Melbourne, FL 32901, USA \\ ${ }^{3}$ Department of Applied Ocean Physics and Engineering, Woods Hole Oceanographic Institution, Woods Hole, MA 02543, USA
}

\begin{abstract}
Covering behavior refers to the propensity of echinoids (Echinoidea) to lift materials from the surrounding environment onto their aboral surfaces using their tube feet and spines. This behavior has been widely documented in regular echinoids from a variety of well-lit, shallowmarine habitats. Covering behavior in the deep sea, however, is rarely observed, and the functional significance of covering when it does occur remains speculative. During a photographic survey of the seafloor off Anvers Island and Marguerite Bay along the western Antarctic Peninsula, we imaged 11 benthic transects at depths ranging from 390 to $2100 \mathrm{~m}$. We recorded the number of echinoid species, incidence of covering behavior, types of materials used for covering, potential predators of echinoids, and potential prey items for predators. The echinoid Sterechinus spp. was found at all depths, and the percentage of individuals exhibiting covering behavior increased with depth between 390 and $1500 \mathrm{~m}$. There was a significant positive correlation between the incidence of covering behavior in Sterechinus spp. and the density of king crabs (Anomura: Lithodidae), crushing predators that may be expanding their bathymetric range up the Antarctic continental slope as a consequence of ongoing climatic warming. In contrast, covering behavior was not positively correlated with the densities of non-crab predators, the total densities of predators, or the availability of prey. Our results document rarely observed covering behavior in echinoids living in the deep sea and suggest that covering could be a behavioral response to predation pressure by king crabs.
\end{abstract}

KEY WORDS: Antarctic Peninsula $\cdot$ Echinoid $\cdot$ Covering behavior $\cdot$ Echinodermata $\cdot$ King crab $\cdot$ Lithodidae

\section{INTRODUCTION}

The Southern Ocean is home to an abundant and diverse marine fauna, despite its isolated location and harsh environmental conditions. Marine organisms living in Antarctic waters tolerate cold temperatures, extreme seasonality in light levels, and episodic ice scour (Peck et al. 2006, Clarke 2008, Griffiths 2010, Chown et al. 2015) and are welladapted to these conditions.

\footnotetext{
${ }^{*}$ Corresponding author: brotce@uab.edu
}

The Echinodermata are relatively well studied and documented within the Southern Ocean. Within the described echinoderms, there are currently 80 accepted Antarctic echinoid species (De Broyer et al. 2015). Their abundance, relatively large size, and calcified tests and spines make them comparatively easy to observe and sample (Linse et al. 2008).

Echinoids of the genus Sterechinus have a circumAntarctic distribution and are the dominant echinoids in many regions, including shallow, nearshore

() The authors 2016. Open Access under Creative Commons by Attribution Licence. Use, distribution and reproduction are unrestricted. Authors and original publication must be credited. Publisher: Inter-Research · www.int-res.com 
waters off the western Antarctic Peninsula (White et al. 2012), the Weddell Sea (Brey \& Gutt 1991), and the Ross Sea (Brey et al. 1995). Five species compose this genus, all of which are found predominately in the Antarctic region (Díaz et al. 2011). Due to their abundance, size, and generalist feeding habits, Sterechinus spp. play an important role in regulating the biomass and species composition of bryozoans (De Ridder \& Lawrence 1982) as well as other macroinvertebrates and, occasionally, drift macroalgae (reviewed by McClintock 1994). It has been suggested that Sterechinus spp. influence the overall benthic community structure of the Southern Ocean (Brey \& Gutt 1991, Brey et al. 1995).

Sterechinus spp. in Antarctic waters have been observed lifting materials, such as stones, shells, and algae, from the surrounding substrate onto their aboral surfaces using their tube feet and spines (Dayton et al. 1970, Amsler et al. 1999). Such 'covering behavior' is well documented in echinoids across a wide range of temperate and tropical shallow marine habitats, including rocky shores (Paracentrotus lividus; Barnes \& Crook 2001), seagrass beds (Lytechinus variegatus, Amato et al. 2008; Tripneustes ventricosus, Kehas et al. 2005), tidepool boreholes (Strongylocentrotus purpuratus and Paracentrotus lividus; Verling et al. 2004), and rhodolith beds (Toxopneustes roseus; James 2000). Covering behavior could play a variety of functional roles, including protection from ultraviolet (UV) radiation (Millott 1956, Adams 2001, Kehas et al. 2005), prevention of dislodgement under high wave surge (Levin et al. 2001, Dumont et al. 2007) and predator avoidance (Agatsuma 2001, Amsler et al. 1999). For example, when juvenile Strongylocentrotus intermedius were exposed in laboratory experiments to the predatory crab Pugettia quadridens, echinoids that were offered shells to cover themselves were more likely to survive than echinoids not offered shells (Agatsuma 2001). Sterechinus neumayeri collected from shallow-water sites in McMurdo Sound cover themselves predominately with the red macroalgae Phyllophora antarctica and Iridaea cordata, which increase this echinoid's ability to escape from encounters with the large, predatory sea anemone Isotealia antarctica (Amsler et al. 1999).

Covering behavior in deep sea echinoids, however, has rarely been observed. Pawson \& Pawson (2013) observed in situ covering behavior in 3 species of echinoids: the regular echinoid Lytechinus euerces and the irregular echinoids Palaeobrissus hilgardi and Conolampas sigsbei, at depths ranging from 272 to $611 \mathrm{~m}$. David et al. (2003) documented the settlement of a wide diversity of meso-invertebrates on the aboral surface of the irregular pourtalesiid Cystocrepis setigera at depths of approximately $2500 \mathrm{~m}$. Additionally, Levin et al. (2001) observed covering behavior - primarily using clusters of foraminiferans - in 1 individual of the irregular spatangoid Cystochinus loveni collected from a depth of $3088 \mathrm{~m}$.

The functional significance of covering behavior in deep-sea echinoids remains speculative because UV radiation is attenuated in the deep sea, and currents and predator-prey interactions are poorly understood. Pawson \& Pawson (2013) concluded that covering behavior in deep-sea echinoids may be a reflexive reaction to available covering materials and/or function in protection of the apical pores. David et al. (2003) suggested that epizoism, phoresis, and commensalism may be partially responsible for the meso-invertebrate settlement observed on Cystocrepis setigera. Levin et al. (2001) suggested that chemical camouflage and/or preventing dislodgement by surge were the most likely explanations for covering behavior in Cystochirus loveni. The goals of the present study were to determine whether deepsea echinoids in Antarctica exhibit covering behavior, whether covering behavior changes with depth, and what, if any, functional significance might be ascribed to covering behavior.

\section{MATERIALS AND METHODS}

\section{Survey methods}

In November 2013, we carried out a photographic survey of the deep seafloor off Anvers Island $\left(63.53^{\circ} \mathrm{S}, 66.05^{\circ} \mathrm{W}\right.$ to $\left.64.30^{\circ} \mathrm{S}, 67.43^{\circ} \mathrm{W}\right)$ and Marguerite Bay $\left(64.11^{\circ} \mathrm{S}, 66.38^{\circ} \mathrm{W}\right.$ to $\left.64.16^{\circ} \mathrm{S}, 66.52^{\circ} \mathrm{W}\right)$ off the western Antarctic Peninsula during cruise NBP13-10 of the RV 'Nathaniel B. Palmer'. We imaged 11 benthic transects, covering a total length of $94686 \mathrm{~m}$, at depths ranging from 390 to $2100 \mathrm{~m}$ using SeaSled, a towed-camera vehicle (Singh et al. 2007, Eastman et al. 2013). SeaSled was outfitted with 2 cameras $(1360 \times 1024$ and $1620 \times 1220$ pixels $)$, which took paired, slightly overlapping images every $6 \mathrm{~s}$, creating photo-transects averaging approximately $2 \mathrm{~m}$ in width and $9 \mathrm{~km}$ in length. SeaSled was also equipped with an acoustic-doppler current profiler (ADCP; $1200 \mathrm{kHz}$ Teledyne RD Instruments), a Paroscientific depth sensor, and a CTD (SeabirdSBE49FastCAT16-HzCTD).

Images obtained from the port-side camera were of lower quality than those from the starboard camera. Consequently, only images from the starboard cam- 
era and taken from a maximum altitude of $4 \mathrm{~m}$ were analyzed in the present study. Images taken at altitudes above $4 \mathrm{~m}$ lacked clarity and could not be accurately analyzed. A total of 15597 images were analyzed, covering a total area of $62988 \mathrm{~m}^{2}$. Each image transect was divided into $250 \mathrm{~m}$ depth bins, and all megafauna were identified to the lowest possible taxonomic level. Megafauna were classified into categories that included potential predators of echinoids (actiniarian sea anemones, nemertean worms, lithodid crabs, octopods, rajid skates, and teleostean fishes), potential prey items (echinoids and holothurians), or both (the sunstars Labidiaster spp. and other asteroids). Only transects with $>100 \mathrm{~m}^{2}$ of seafloor per depth bin were used; consequently, no data were analyzed from the 1500$1750 \mathrm{~m}$ depth bin.

The number of echinoids displaying covering behavior and the types of covering materials held by individual species were recorded. The percentage of echinoids displaying covering behavior was only calculated if transects contained $>8$ individuals per depth bin. The availability of covering materials was determined by recording the number and type of covering materials visible on the seafloor for 15 randomly selected images per depth bin.

\section{Statistical analyses}

GraphPad Prism 6 and R software (R Core Team 2015) were used to conduct all statistical analyses. Data were tested for normality and homoscedasticity prior to statistical analysis. The percentage of echinoids displaying covering behavior across depth bins was square-root-transformed and analyzed using a 1-way analysis of variance (1-way ANOVA). There were no significant differences between echinoid density and the incidence of covering behavior between the 2 sites, Anvers Island and Marguerite Bay; therefore, transects from these 2 sites were combined. The types of covering materials used by echinoids and those available across depth bins were analyzed using the $\mathrm{R}$ vegan package, Adonis function, and similarity percentage analysis (SIMPER). Correlations between the percentage of echinoids displaying covering behavior and the other variables examined in this study (total availability of covering materials, availability of shell/echinoid-test hash, relative availability of shell/echinoid-test hash [= availability / Sterechinus spp. density], density of individual potential predators of echinoids, overall predator density, total availability of potential prey items, rel- ative availability of potential prey items [= availability / predator density], and seawater temperature) were analyzed using the Spearman rank-order coefficient. The seawater temperature of transects across depth bins was analyzed using a 1-way ANOVA.

\section{RESULTS}

The irregular echinoid Abatus spp., as well as 2 genera of regular echinoids, Ctenocidaris spp., and Sterechinus spp., were imaged in our survey transects off the western Antarctic Peninsula, but only Sterechinus spp. exhibited covering behavior. Individuals of this genus were observed in all depth bins, with the highest mean density of 53.47 ind. $1000 \mathrm{~m}^{-2}$ observed in the 750-1000 m depth bin (Fig. 1). Sterechinus spp. living at deeper depths of 1000-1250 and 1250-1500 $\mathrm{m}$ at the study sites displayed a significantly higher incidence of covering behavior $(67.97 \pm 5.14 \%$ and $83.24 \pm 2.47 \%$ respectively; mean $\pm \mathrm{SE}$ ) than echinoids living at shallower depths (390$500 \mathrm{~m} ; 4.49 \% \pm 2.43$; 1 -way ANOVA, $F_{4,7}=12.68, \mathrm{p}=$ 0.0025; Fig. 2).

Sterechinus spp. were observed covering their aboral tests with algae, bryozoans, whole echinoid tests, and shell/echinoid-test hash (Fig. 3). The types of covering materials used by individuals changed with depth bin (Adonis, $F_{4,167}=3.969, \mathrm{R}^{2}=0.08681$, $\mathrm{p}=0.002$; Fig. $4 \mathrm{a})$, with the dissimilarity between the shallowest depth bin (390-500 m) and all other depth bins being $>72 \%$. This dissimilarity was primarily

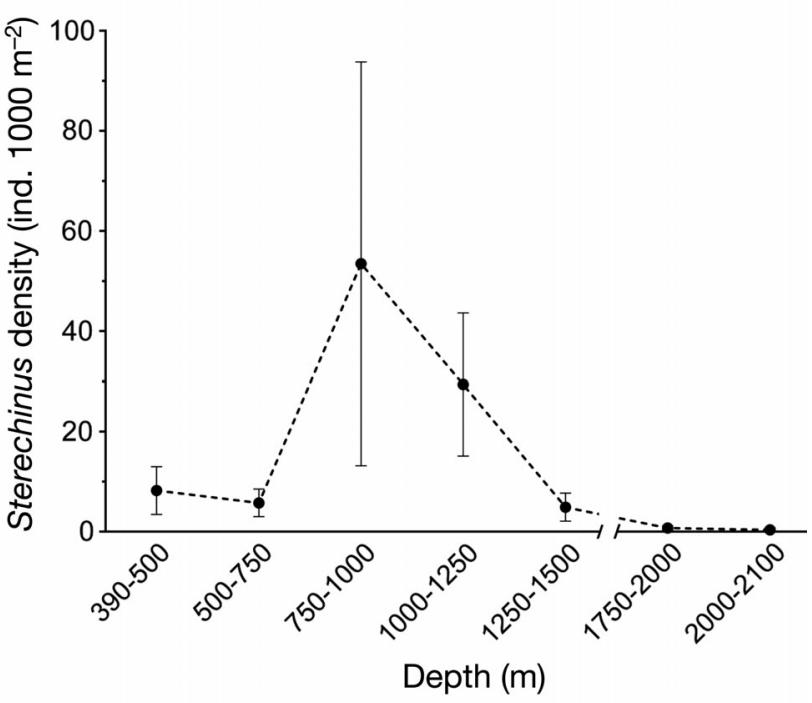

Fig. 1. Density (mean $\pm 1 \mathrm{SE}$ ) of Sterechinus spp. on the continental shelf and slope (390-2100 m) off the western Antarctic Peninsula. Data represent combined counts from Marguerite Bay and Anvers Island 


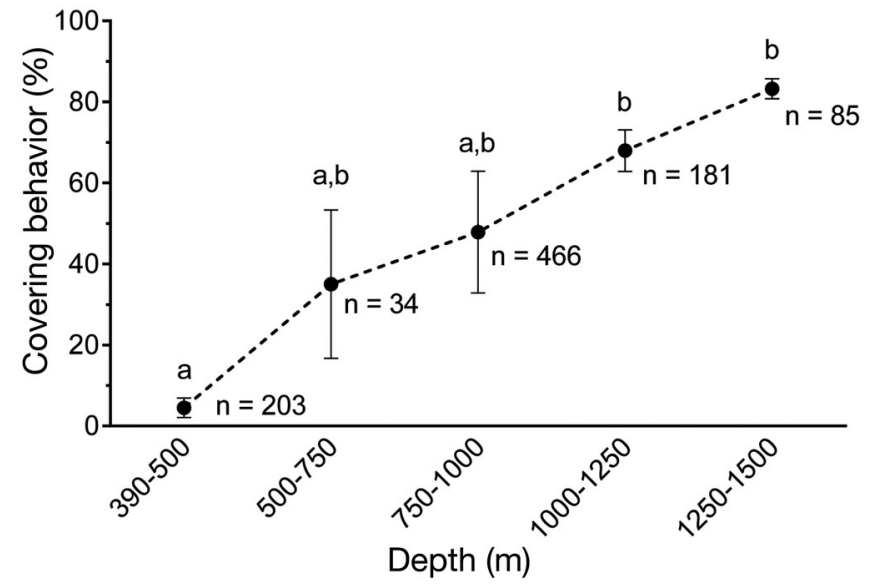

Fig. 2. Covering behavior (mean $\pm 1 \mathrm{SE}$ ) of Sterechinus spp. on the continental shelf and slope (390-1500 m) off the western Antarctic Peninsula. Data represent combined counts from Marguerite Bay and Anvers Island. Different lowercase letters indicate significant differences between $250 \mathrm{~m}$ depth bins

driven by the change in covering materials from algae and/or bryozoans in shallower water to shell/ echinoid-test hash in deeper water (see Table S1 in the Supplement at www.int-res.com/articles/suppl/ m533p155_supp.pdf). At depths of 390 to $500 \mathrm{~m}$, $63.6 \%$ of covered individuals of Sterechinus spp. used drift algae and/or bryozoans as covering material, 9.1\% used whole echinoid tests, and $27.3 \%$ used shell/echinoid-test hash. However, as depth increased, individuals covered with shell/echinoid-test hash more frequently. For example, in the 1250-
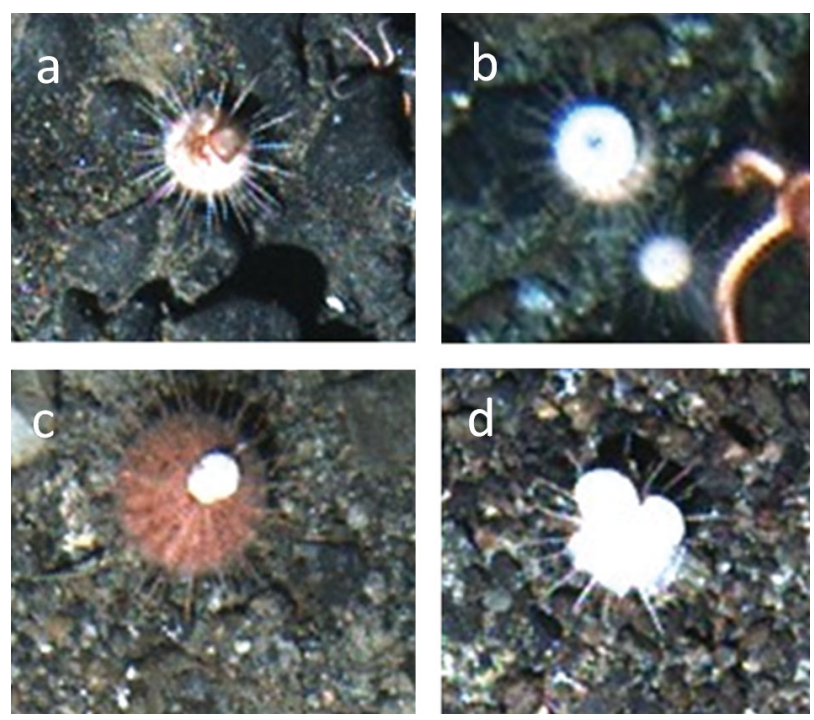

Fig. 3. Representative digital images of Sterechinus spp. along imaged transects that have covered their aboral test with (a) algae/bryozoans, (b) whole echinoid tests, and (c,d) shell/echinoid-test hash
$1500 \mathrm{~m}$ depth bin, $7.1 \%$ of the covered Sterechinus spp. used drift algae and/or bryozoans as covering material, $7.1 \%$ used whole echinoid tests, and $85.7 \%$ used shell/echinoid-test hash.

The types of covering materials available in the surrounding environment also changed with depth (Adonis, $F_{4,55}=2.3088, \mathrm{R}^{2}=0.14377, \mathrm{p}=0.028$; Fig. $4 \mathrm{~b}$ ), with the dissimilarity between the shallowest depth bin (390-500 m) and all other depth bins being $>48 \%$. This dissimilarity was primarily driven by the change in the availability of shell/echinoidtest hash as covering materials (see Table S2 in the Supplement). At depths of 390 to $500 \mathrm{~m}, 31.6 \%$ of the available covering material was drift algae and/or bryozoans, $21.1 \%$ was whole echinoid tests, and $47.4 \%$ was shell/echinoid-test hash, whereas at depths of 1250 to $1500 \mathrm{~m}, 1.9 \%$ of the available covering material was drift algae and/or bryozoans, $1.9 \%$ was whole echinoid tests, and $96.3 \%$ was shell/echinoid-test hash. Although the types of materials used to cover the aboral test changed, there was a) Covering material used

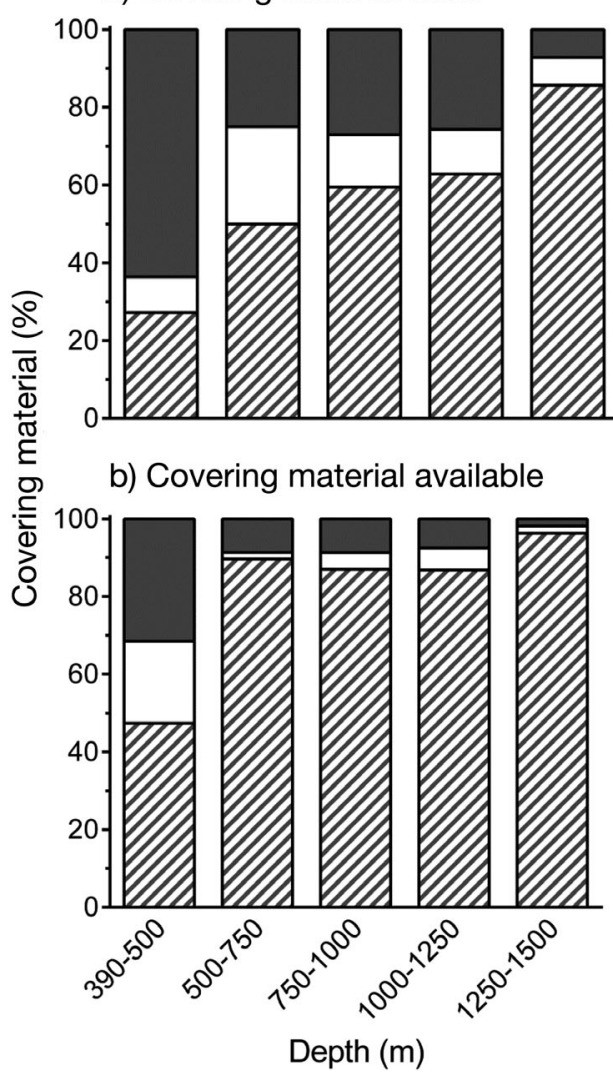

Fig. 4. Percentage of different covering materials (a) used by Sterechinus spp. for covering and (b) available for covering across $250 \mathrm{~m}$ depth bins imaged between 390 and $1500 \mathrm{~m}$ depth off the western Antarctic Peninsula. Data represent combined counts from Marguerite Bay and Anvers Island 
no significant correlation between the incidence of covering behavior and the total availability of covering materials (Spearman's rank-order correlation, $\mathrm{r}_{\mathrm{s}}=$ $0.7, p=0.233$ ). Because of the change in availability of shell/echinoid-test hash driving the shift in total availability of covering materials, we further examined the possibility of a relationship between the incidence of covering behavior and the availability or relative availability (calculated as availability/ Sterechinus spp. density) of shell/echinoid-test hash for covering materials, but there was no significant correlation $\left(\mathrm{r}_{\mathrm{s}}=-0.8, \mathrm{p}=0.086\right.$ and $\mathrm{r}_{\mathrm{s}}=-0.5, \mathrm{p}=$ 0.360 , respectively).

There was a significant positive correlation between the incidence of covering behavior and the density of lithodids $\left(\mathrm{r}_{\mathrm{s}}=0.975, \mathrm{p}=0.033\right)$, with the highest incidence of covering behavior (83.24\%) observed at lithodid densities of 1.30 ind. $1000 \mathrm{~m}^{-2}$ (Fig. 5). However, the incidence of covering behavior was not positively correlated with the densities of any other potential predators of echinoids, such as actiniarian sea anemones $\left(\mathrm{r}_{\mathrm{s}}=-0.851, \mathrm{p}=0.041\right)$, nemertean worms $\left(\mathrm{r}_{\mathrm{s}}=-0.872, \mathrm{p}=0.033\right)$, octopods $\left(\mathrm{r}_{\mathrm{s}}=-0.1, \mathrm{p}=0.95\right)$, rajid skates $\left(\mathrm{r}_{\mathrm{s}}=-0.2, \mathrm{p}=0.783\right)$, or teleostean fish $\left(\mathrm{r}_{\mathrm{s}}=-0.5, \mathrm{p}=0.45\right)$. Additionally, the incidence of covering behavior was not significantly correlated with the total predator density $\left(\mathrm{r}_{\mathrm{s}}=\right.$ $-0.9, p=0.083)$, the availability of potential prey items $\left(r_{s}=-0.7, p=0.233\right)$, or the relative availability (availability / predator density) of potential prey items $\left(\mathrm{r}_{\mathrm{s}}=0.7, \mathrm{p}=0.233\right)$.

In the 11 transects, salinity remained constant at 35 , and temperature ranged from 0.43 to $1.62^{\circ} \mathrm{C}$. There was a significant difference in mean seawater temperature among depth bins (1-way ANOVA,

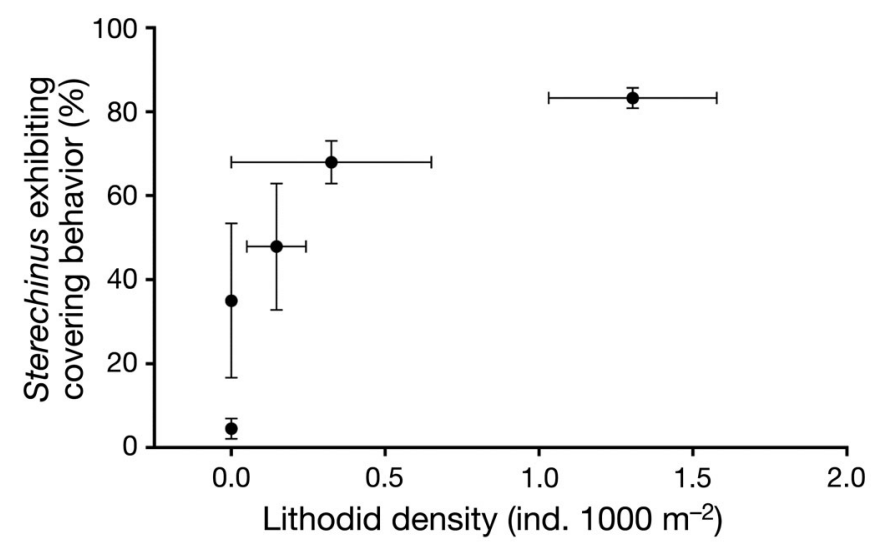

Fig. 5. Mean ( $\pm 1 \mathrm{SE})$ density of lithodids and percentage of Sterechinus spp. exhibiting covering behavior across $250 \mathrm{~m}$ depth bins between 390 and $1500 \mathrm{~m}$ depth. Data represent combined counts from Marguerite Bay and Anvers Island
$\left.F_{5,15}=17.52, \mathrm{p}<0.0001\right)$. The mean seawater temperature of transects between 390 and $500 \mathrm{~m}$ was $1.42^{\circ} \mathrm{C}$ and decreased steadily to depths between 2000 and $2100 \mathrm{~m}$, where the mean seawater temperature was $0.47^{\circ} \mathrm{C}$. The incidence of covering behavior was inversely correlated with the seawater temperature of the depth bins (Spearman's rank-order correlation, $\left.r_{s}=-1.0, p=0.017\right)$.

\section{DISCUSSION}

Sterechinus spp. were observed in all depth bins between 390 and $2100 \mathrm{~m}$. The 5 species that compose this genus are identifiable by morphological and biogeographical characteristics (Díaz et al. 2011). Two of these 5 species have limited biogeographic distributions: $S$. diadema inhabits the continental shelf (15-750 m) surrounding the subantarctic Kerguelen Islands, and $S$. agassizii inhabits the continental shelf and slope (10-1000 m) off the east coast of Argentina (David et al. 2005). The remaining 3 species display a circum-Antarctic distribution (Díaz et al. 2011). Sterechinus neumayeri is the most common species from shallow, coastal depths down to $450 \mathrm{~m}$, although on occasion it can be found down to $850 \mathrm{~m}$ (Brey \& Gutt 1991, Díaz et al. 2011). In a field survey of 5 shallow sites near Anvers Island at depths ranging from 2 to $15 \mathrm{~m}$, the density of $S$. neumayeri was approximately 3400 ind. $1000 \mathrm{~m}^{-2}$ (White et al. 2012). At depths below $450 \mathrm{~m}$, another species, $S$. antarcticus, is by far the most common species, with densities on the Weddell Sea shelf and slope measured at 24 ind. $1000 \mathrm{~m}^{-2}$ (Brey \& Gutt 1991) and a depth-range of 30-2000 m (Díaz et al. 2011). It should be noted that $S$. antarctiCus, S. agassizii, and $S$. diadema may be closely related or phenotypes of a single species (Díaz et al. 2011). Finally, S. dentifer occurs between 1200 and $1600 \mathrm{~m}$ but is relatively uncommon (Jacob et al. 2003, Moya et al. 2012).

The quality of the seafloor images and the absence of specimens for identification by morphological and molecular techniques limited our ability to identify the Sterechinus to species level. Based on known biogeographic distributions, depth ranges, and patterns of abundance, however, it is probable that although some of the individuals observed in our imaged transects were $S$. dentifer, the vast majority were $S$. antarcticus (Díaz et al. 2011, E. Poulin pers. comm.).

Covering behavior has previously been documented in $S$. neumayeri at shallow depths. Dayton et al. (1970) observed S. neumayeri at Cape Armitage, Mc- 
Murdo Sound, Antarctica, covering itself with shell debris and pieces of algae that were themselves covered with stinging hydroids, and they suggested that this was a physical defense against the common, large, predatory sea anemone Urticinopsis antarctica. Aggregations of this anemone are found in depths down to $420 \mathrm{~m}$ (Häussermann 2006); the anemones commonly feed on echinoids and seastars, with $S$. neumayeri comprising $65 \%$ of their diet (Dayton et al. 1970). In laboratory experiments conducted by Amsler et al. (1999), the sea anemone Isotealia antarctica caught and consumed 70 to $80 \%$ of uncovered S. neumayeri upon contact; however, when the echinoids were allowed to cover themselves with red algae, only $5 \%$ of echinoids encountering a sea anemone were captured and eaten. Although covering behavior may be an effective antipredatory response for echinoids encountering anemones at shallow depths, these predatory anemones are not present at the deep depths examined in the present study.

In nearshore, shallow waters of tropical and temperate regions, predators of echinoids include fish (McClanahan \& Shafir 1990, Sala \& Zabala 1996), spiny lobsters (Tegner \& Levin 1983), crabs (Scheibling \& Hamm 1991, Agatsuma 2001, Gudimov et al. 2003), sea stars (Urriago et al. 2011), and sea otters (Estes \& Palmisano 1974). In the Southern Ocean, however, there are few durophagous (skeletonbreaking) predators (Aronson et al. 2007, 2015). Brachyuran crabs, lobsters, and sharks are absent, and there are only a few species of skates, anomuran crabs, and teleostean fish (Aronson et al. 2007, Clarke et al. 2004). Potential predators of echinoids observed in the present study included actiniarian sea anemones, nemertean worms, lithodid crabs, the sunstars Labidiaster spp., other asteroids, octopods, rajid skates, and teleostean fish. With the notable exception of lithodid crabs, which could be a recent addition to the suite of predators on the Antarctic slope (Aronson et al. 2007, 2015), there was no significant positive correlation between the occurrence of echinoid covering behavior and the abundance of any of these predators. Covering behavior increased with increasing density of lithodids, apparently reaching a threshold above 1 ind. $1000 \mathrm{~m}^{-2}$ (Fig. 5).

The majority of lithodids in Marguerite Bay are likely Paralomis birsteini (Aronson et al. 2015). Preliminary data from gut-content analyses indicate that echinoderms, including echinoids, are major components of the diet of $P$. birsteini $>40 \%$ of lithodid guts analyzed contained echinoid parts. In the Beagle Channel, Tierra del Fuego, Argentina, echinoderms, primarily the echinoid Pseudechinus magellanicus, constituted $47 \%$ of the diet of the false southern king crab Paralomis granulosa (Comoglio \& Amin 1999). Furthermore, in the Arctic, echinoids are a principal component of the diet of the red king crab Paralithodes camtschaticus, where it has been introduced (Gudimov et al. 2003). The P. camtschaticus population in the Barents Sea can consume one-sixth of the Strongylocentrotus spp. stock each year (Gudimov et al. 2003), a factor that may be contributing to decreasing echinoid populations (reviewed by FalkPetersen et al. 2011). The significant, positive correlation we observed in the present study between the incidence of echinoid covering behavior and the population density of king crabs suggests an antipredatory response. Sterechinus spp. could be covering themselves to reduce the incidence of predation by lithodids. Alternatively, the lithodids, which are present in higher densities at deeper depths, could be preferentially consuming uncovered Sterechinus spp.

The mechanism by which covering in Sterechinus spp. might reduce predation from lithodids in Antarctica is unknown, but in other instances in which echinoids use covering behavior to reduce predation, the covering material provides a physical - rather than a behavioral or chemical - defense against predation (Amsler et al. 1999, Dayton et al. 1970). A primary consideration for predatory crabs is the handling time of their invertebrate prey. Skeletonized prey, such as barnacles and oysters, have evolved heavy shells and ornamentation that increase handling time (Seitz et al. 2001). Sea urchins may cover themselves to increase handling time, reducing their risk of mortality from predation.

In situ covering behavior in echinoids has been observed in other species of Sterechinus inhabiting nearshore shallow waters along the western Antarctic Peninsula (Amsler et al. 1999, White et al. 2012) as well as in the Weddell Sea (D. Gerdes pers. comm.) and in Explorer's Cove in McMurdo Sound (P. K. Dayton pers. comm.). It should be noted that these are environments where to date no king crabs have been observed. Similar to echinoids in temperate and tropical areas (Barnes \& Crook 2001), the functional significance of covering behavior in Sterechinus spp. may vary among species and populations.

Echinoids in deeper water (1000-1500 m) displayed covering behavior significantly more frequently than those at shallower depths (390-500 m). Although our study did not measure UV radiation or current speed, both of which can affect covering behavior in shallow-water echinoids (Adams 2001, Levin et al. 2001, Kehas et al. 2005, Dumont et al. 2007), it is unlikely that either of these factors would 
have affected echinoids living in the deep sea more so than those living at shallower depths. In the Southern Ocean, biologically relevant levels of UV-B radiation only extend down to $30 \mathrm{~m}$ (Karentz 1994), and currents in our images appeared relatively weak. Echinoid covering behavior was inversely correlated with seawater temperature; however, there is no reason to believe that echinoids were responding to decreasing seawater temperatures. Instead, seawater temperatures may physiologically limit the depth distribution of lithodids (Aronson et al. 2015). Our study indicates that covering behavior is not a tactile response to available or specific covering materials or a general response to increased total predator density. Mann et al. (1984) established that echinoids are able to detect water-borne cues from predatory crabs and respond by changing their behavior. Additionally, Urriago et al. (2011) demonstrated that echinoids are able to differentiate between species of predatory seastars using distance chemodetection and respond according to the risk of predation. Although manipulative inclusion/exclusion experiments would be necessary to demonstrate causality, chemodetection of lithodids could be responsible for the increased incidence of echinoid covering at deeper depths, coincident with the greater abundance of king crabs.

Warming seawater temperatures due to anthropogenic climate change may not only facilitate the movement of king crabs up and onto the Antarctic continental shelf (Aronson et al. 2015) but also may impede covering behaviors of echinoids. Stenothermal polar-marine invertebrates, including Sterechinus neumayeri, are physiologically, developmentally, and behaviorally challenged by even small increases in seawater temperature (Sewell \& Hofmann 2011, Branco et al. 2012, Byrne et al. 2013). Moreover, the shallow-water, subtropical echinoid Lytechinus variegatus loses its ability to cover when exposed to near-future elevated seawater temperature (Brothers \& McClintock 2015). Should a temperature rise similarly impair covering in Antarctic echinoids, they could become more vulnerable to predators, including lithodids.

Acknowledgements. We thank the crew of the RV 'Nathaniel B. Palmer' during the NBP13-10 cruise for logistical help, as well as J. S. Anderson, A. Brown, C. Easson, D. Ellis, S. Thatje, and S. C. Vos. Thanks also to Paul Dayton as well as 2 anonymous reviewers who offered constructive comments and suggestions. Funding was provided by grants from the US National Science Foundation to R.B.A. (ANT1141877) and J.B.M. (ANT-1141896). This paper is contribution no. 160 from the Institute for Research on Global Climate Change at the Florida Institute of Technology.

\section{LITERATURE CITED}

Adams NL (2001) UV radiation evokes negative phototaxis and covering behavior in the sea urchin Strongylocentrotus droebachiensis. Mar Ecol Prog Ser 213:87-95

Agatsuma Y (2001) Effect of the covering behavior of the juvenile sea urchin Strongylocentrotus intermedius on predation by the spider crab Pugettia quadridens. Fish Sci 67:1181-1183

Amato KR, Emel SL, Lindgren CA, Sullan KM, Wright PR, Gilbert JJ (2008) Covering behavior of two co-occurring Jamaican sea urchins: differences in the amount of covering and selection of covering material. Bull Mar Sci 82: 255-261

Amsler CD, McClintock JB, Baker BJ (1999) An antarctic feeding triangle: defensive interactions between macroalgae, sea urchins, and sea anemones. Mar Ecol Prog Ser 183:105-114

Aronson RB, Thatje S, Clarke A, Peck LS, Blake DB, Wilga CD, Seibel BA (2007) Climate change and invasibility of the Antarctic benthos. Annu Rev Ecol Evol Syst 38: 129-154

Aronson RB, Smith KE, Vos SC, McClintock JB and others (2015) No barrier to shoreward expansion of bathyal king crabs on the Antarctic Shelf. Proc Natl Acad Sci USA 112: 12997-13002

> Barnes D, Crook A (2001) Quantifying behavioural determinants of the coastal European sea-urchin Paracentrotus lividus. Mar Biol 138:1205-1212

Branco PC, Pressinotti LN, Borges JCS, Iunes RS and others (2012) Cellular biomarkers to elucidate global warming effects on Antarctic sea urchin Sterechinus neumayeri. Polar Biol 35:221-229

> Brey T, Gutt J (1991) The genus Sterechinus (Echinodermata: Echinoidea) on the Weddell Sea shelf and slope (Antarctica): distribution, abundance and biomass. Polar Biol 11:227-232

Brey T, Pearse J, Basch L, McClintock J, Slattery M (1995) Growth and production of Sterechinus neumayeri (Echinoidea: Echinodermata) in McMurdo Sound, Antarctica. Mar Biol 124:279-292

Brothers CJ, McClintock JB (2015) The effects of climateinduced elevated seawater temperature on the covering behavior, righting response, and Aristotle's lantern reflex of the sea urchin Lytechinus variegatus. J Exp Mar Biol Ecol 467:33-38

Byrne M, Ho MA, Koleits L, Price C and others (2013) Vulnerability of the calcifying larval stage of the Antarctic sea urchin Sterechinus neumayeri to near-future ocean acidification and warming. Glob Chang Biol 19:2264-2275

- Chown SL, Clarke A, Fraser CI, Cary SC, Moon KL, McGeoch MA (2015) The changing form of Antarctic biodiversity. Nature 522:431-438

> Clarke A (2008) Antarctic marine benthic diversity: patterns and processes. J Exp Mar Biol Ecol 366:48-55

> Clarke A, Aronson RB, Crame JA, Gili JM, Blake DB (2004) Evolution and diversity of the benthic fauna of the Southern Ocean continental shelf. Antarct Sci 16:559-568

Comoglio LI, Amin OA (1999) Feeding habits of the false southern king crab Paralomis granulosa (Lithodidae) in the Beagle Channel, Tierra del Fuego, Argentina. Sci Mar 63:361-366

David B, Magniez F, Villier L, De Wever P (2003) Conveying behavior of the deep sea pourtalesiid Cystocrepis setigera off Peru. In: Féral JP, David B (eds) Proc 6th Eur Conf Echinoderm Res. A. A. Balkema, Lisse, p 253-257

> David B, Choné T, Festeau A, Mooi R, De Ridder C (2005) 
Biodiversity of Antarctic echinoids: a comprehensive and interactive database. Sci Mar 69:201-203

Dayton PK, Robillard GA, Paine RT (1970) Benthic faunal zonation as a result of anchor ice at McMurdo Sound, Antarctica. In: Holdgate MW (ed) Antarctic ecology, Vol. 1. Academic Press, New York, NY, p 244-258

De Broyer C, Clarke A, Koubbi P, Pakhomov E, Scott F, Vanden Berghe E, Danis B (eds) (2015) Register of Antarctic marine species. Available at www.marinespecies.org/ rams (accessed 7 Oct 2015)

De Ridder C, Lawrence JM (1982) Food and feeding mechanisms: Echinoidea. In: Lawrence JM, Jangoux M (eds) Echinoderm nutrition. A. A. Balkema, Rotterdam, p 57-115

Díaz A, Féral JP, David B, Saucède T, Poulin E (2011) Evolutionary pathways among shallow and deep-sea echinoids of the genus Sterechinus in the Southern Ocean. Deep-Sea Res II 58:205-211

Dumont CP, Drolet D, Deschênes I, Himmelman JH (2007) Multiple factors explain the covering behaviour in the green sea urchin, Strongylocentrotus droebachiensis. Anim Behav 73:979-986

Eastman JT, Amsler MO, Aronson RB, Thatje S and others (2013) Photographic survey of benthos provides insights into the Antarctic fish fauna from the Marguerite Bay slope and the Amundsen Sea. Antarctic Sci 25:31-43

- Estes JA, Palmisano JF (1974) Sea otters: their role in structuring nearshore communities. Science 185:1058-1060

Falk-Petersen J, Renaud P, Anisimova N (2011) Establishment and ecosystem effects of the alien invasive red king crab (Paralithodes camtschaticus) in the Barents Sea-a review. ICES J Mar Sci 68:479-488

Griffiths HJ (2010) Antarctic marine biodiversity - what do we know about the distribution of life in the Southern Ocean? PLoS ONE 5:e11683

> Gudimov AV, Gudimova EN, Pavlova LV (2003) Effect of the red king crab Paralithodes camtschaticus on the Murmansk coastal macrobenthos: the first estimates using sea urchins of the genus Strongylocentrotus as an example. Dokl Biol Sci 393:539-541

> Häussermann V (2006) Biodiversity of Chilean sea anemones (Cnidaria: Anthozoa): distribution patterns and zoogeographic implications, including new records for the fjord region. Investig Mar 34:23-35

> Jacob U, Terpstra S, Brey T (2003) High-Antarctic regular sea urchins-the role of depth and feeding in niche separation. Polar Biol 26:99-104

James D (2000) Diet, movement, and covering behavior of the sea urchin Toxopneustes roseus in rhodolith beds in the Gulf of California, México. Mar Biol 137:913-923

Karentz D (1994) Ultraviolet tolerance mechanisms in Antarctic marine organisms. In: Weiler CS, Penhale PA (eds) Ultraviolet radiation in Antarctica: measurements and biological effects. Antarctic research series, Vol 62. American Geophysical Union, Washington, DC, p 93-110

Kehas AJ, Theoharides KA, Gilbert JJ (2005) Effect of sunlight intensity and albinism on the covering response of the Caribbean sea urchin Tripneustes ventricosus. Mar Biol 146:1111-1117

Levin LA, Gooday AJ, James DW (2001) Dressing up for the deep: agglutinated protists adorn an irregular urchin. J Mar Biol Assoc UK 81:881-882

Linse K, Walker LJ, Barnes DK (2008) Biodiversity of echi- noids and their epibionts around the Scotia Arc, Antarctica. Antarct Sci 20:227-244

Mann KH, Wright JL, Welsford BE, Hatfield E (1984) Responses of the sea urchin Strongylocentrotus droebachiensis (OF Müller) to water-borne stimuli from potential predators and potential food algae. J Exp Mar Biol Ecol 79:233-244

McClanahan T, Shafir S (1990) Causes and consequences of sea urchin abundance and diversity in Kenyan coral reef lagoons. Oecologia 83:362-370

McClintock JB (1994) Trophic biology of antarctic shallowwater echinoderms. Mar Ecol Prog Ser 111:191-202

Millott N (1956) The covering reaction of sea-urchins I. A preliminary account of covering in the tropical echinoid Lytechinus variegatus (Lamarck), and its relation to light. J Exp Biol 33:508-523

Moya F, Saucède T, Majón-Cabeza ME (2012) Environmental control on the structure of echinoid assemblages in the Bellingshausen Sea (Antarctica). Polar Biol 35: 1343-1357

Pawson DL, Pawson DJ (2013) Bathyal sea urchins of the Bahamas, with notes on covering behavior in deep sea echinoids (Echinodermata: Echinoidea). Deep-Sea Res II 92:207-213

$>$ Peck LS, Convey P, Barnes DK (2006) Environmental constraints on life histories in Antarctic ecosystems: tempos, timings and predictability. Biol Rev Camb Philos Soc 81: 75-109

R Core Team (2015) R: a language and environment for statistical computing. R Foundation for Statistical Computing, Vienna, available at www.R-project.org/

Sala E, Zabala M (1996) Fish predation and the structure of the sea urchin Paracentrotus lividus populations in the NW Mediterranean. Mar Ecol Prog Ser 140:71-81

Scheibling RE, Hamm J (1991) Interactions between sea urchins (Strongylocentrotus droebachiensis) and their predators in field and laboratory experiments. Mar Biol 110:105-116

Seitz RD, Lipcius RN, Hines AH, Eggleston DB (2001) Density-dependent predation, habitat variation, and the persistence of marine bivalve prey. Ecology 82:2435-2451

Sewell MA, Hofmann GE (2011) Antarctic echinoids and climate change: a major impact on the brooding forms. Glob Change Biol 17:734-744

Singh H, Roman C, Pizarro O, Eustice R, Can A (2007) Towards high-resolution imaging from underwater vehicles. Int J Robotics Res 26(1):55-74

Tegner M, Levin L (1983) Spiny lobsters and sea urchins: analysis of a predator-prey interaction. J Exp Mar Biol Ecol 73:125-150

> Urriago JD, Himmelman JH, Gaymer CF (2011) Responses of the black sea urchin Tetrapygus niger to its sea-star predators Heliaster helianthus and Meyenaster gelatinosus under field conditions. J Exp Mar Biol Ecol 399: $17-24$

> Verling E, Crook AC, Barnes DK (2004) The dynamics of covering behaviour in dominant echinoid populations from American and European west coasts. Mar Ecol 25: 191-206

White BA, McClintock J, Amsler CD, Mah CL and others (2012) The abundance and distribution of echinoderms in nearshore hard-bottom habitats near Anvers Island, Western Antarctic Peninsula. Antarct Sci 24:554-560

Submitted: January 12, 2016; Accepted: April 20, 2016 Proofs received from author(s): June 30, 2016 